\title{
Differentiation of Menstrual Blood Derived Stem Cell (MensSCs) to Hepatocyte-Liked Cell on Three Dimensional Nanofiberscaffold: Poly Caprolacton (PCL)
}

\author{
Farnaz Sani', Giti Borzooeian², Somayeh Kazemnejad'3, Sepideh Ebrahimi ${ }^{4}$, \\ Masoomeh Mohamadpour ${ }^{5}$, Sayeh Khanjani ${ }^{3}$, Mona Latifi' ${ }^{1}$, \\ Seyed Mojtaba Hosseini' ${ }^{2}$, Mahin Salmannejad', Fatemeh Aleahmad, \\ Hossein Mehraban Jahromi², Mahsa Sani ${ }^{1,3^{*}}$ \\ ${ }^{1}$ Laboratory for Stem Cell Research, Anatomy Department, Shiraz Medical School, Shiraz University of Medical \\ Sciences, Shiraz, Iran \\ ${ }^{2}$ Student Research Committee, Shiraz University of Medical Sciences, Shiraz, Iran \\ ${ }^{3}$ Departments of Embryology and Stem Cells, Reproductive Biotechnology Research Center, Avicenna Research \\ Institute, ACECR, Tehran, Iran \\ ${ }^{4}$ Department of Biochemistry, Shiraz Medical School, Shiraz University of Medical Sciences, Shiraz, Iran \\ ${ }^{5}$ Anatomy, Histomorphometry and Stereology Research Center, Shiraz Medical School, Shiraz University of \\ Medical Sciences, Shiraz, Iran \\ Email: "sani_mahsa@yahoo.com
}

Received 31 October 2015; accepted 26 March 2016; published 29 March 2016

Copyright (C) 2016 by authors and Scientific Research Publishing Inc.

This work is licensed under the Creative Commons Attribution International License (CC BY).

http://creativecommons.org/licenses/by/4.0/

(c) (i) Open Access

\section{Abstract}

Menstrual blood stem cells (MensSCs) have enormous potential as a source for cell replacement therapies. Since there is a major concern in utilization of nanofibers in tissue engineering of stem cells, we examined the potential of MensSCs to differentiate into hepatocytes, using different protocols and compare cells, with two-dimensional (2D) and three-dimensional (3D) culture systems. Cell characterization experiments of MensSCs have demonstrated that they are multipotent stem cells similar to mesenchymal stem cells, which can successfully differentiate into osteogenic and adipogenic lineages. The efficiency of the cells on the scaffold was appraised by scanning electron microscopy (SEM), MTT assay, and hematoxylin and eosin (H\&E) staining. Thereafter, the differentiation protocols were developed by hepatocyte growth factor (HGF) and oncostatin M (OSM) with serum-supplemented or serum-free culture media up to 30 days. Immunofluorescence analysis and ELISA assay revealed the expression of albumin (ALB) in differentiated cells. Hepatocyte-

\footnotetext{
${ }^{*}$ Corresponding author.
}

How to cite this paper: Sani, F., et al. (2016) Differentiation of Menstrual Blood Derived Stem Cell (MensSCs) to Hepatocyte-Liked Cell on Three Dimensional Nanofiberscaffold: Poly Caprolacton (PCL). J. Biomedical Science and Engineering, 9, 216-225. http://dx.doi.org/10.4236/jbise.2016.94016 
like cells expressed liver-specific gene such as albumin(ALB), $\alpha$-fetoprotein (AFP), tyrosine aminotransferase (TAT) and cytochrome P450 subunit 7a1 (Cyp7a1) at mRNA levels. In conclusion, the evidences presented in this study show that the nanofiber scaffold and MensSCs may provide a source of differentiated cells for treatment of liver diseases.

\section{Keywords}

\section{Differentiation, Hepatocyte, Menstrual Blood, Stem Cell, 3D Cultures}

\section{Introduction}

Hepatocyte transplantation could be a superseded solution for people on transplant waiting lists as a replacement for whole organ transplantation [1]. Tissue engineering is rapidly developing. The use of tissue engineering is that scaffold can regenerate the lost or defective tissues by three-dimensional, biodegradable and biocompatible properties that simulate the body's tissues [2]. Poly- $\varepsilon$-caprolactone (PCL) is semi crystalline hydrophobic biodegradable polyester with chemico-physical characteristics and can be used into a convenient scaffold for tissue engineering. PCL degrades very slowly; therefore it is suitable for use in long term load bearing applications [3]. Cell source is an imperative aspect of successful tissue regeneration. It has been suggested that all tissues with a connective tissue or stromal component may contain a population of mesenchymal or stromal stem cells responsible for lifetime tissue regeneration and remodeling [4]. Stromal stem cells have been revealed to have high potential [1] for stem cell-based therapies [5]-[7]. Stem cells derived from menstrual blood have noninvasive methods and no ethical problems of embryonic stem cells. These cells illustrate stem cell-like phenotypic markers and performance high potential for self-renewal, plasticity. The correlation function of the menstrual cycle with Oct-4 as a self-renewal marker of undifferentiated embryonic stem was shown [8]. This cell compared with embryonic stem cells, although the markers expressed in the endometrium do not fully exhibit the embryonic markers leading to the formation of teratoma [9] [10]. A lot of studies have introduced this population as pluripotent cells. They are capable of differentiating into specific-tissue cells of three germ layers both in vitro and in vivo, and play an important role in improving the disease status of study models [11]. In this study differentiation potential of MensSCs to hepatocyte-like cell on nanofiber scaffold was experimented.

\section{Materials and Methods}

\subsection{Chemical and Reagents}

Dulbecco's Modified Eagle’s Medium (DMEM, pH 7.4), fetal bovine serum (FBS), 2 mM l-glutamine, penicillin and streptomycin, non-essential amino acids, fangizone, 0.05\% trypsin-EDTA were obtained from Gibco Life Technologies Co.PCL (70,000 - 90,000 KDa), 3-(4,5-dimethylthiazole-2-yl)-2, 5-diphenyltetrazolium bromide (MTT), insulin-transferrin-selenium + 1 (ITS + 1) premix, Epithelial growth factor (EGF), basic fibroblast growth factor (bFGF), nicotine amid (NTA), Hepatocyte growth factor (HGF), dexamethasone (Dex) were purchased from Sigma-Aldrich Co. and Ficoll-Paque was provided from Amersham Bioscience Co. (Sweden). Antibodies for flowcytometric and Immunofluorescence analysis were prepared from Abcam, UK, Cambridge.

\subsection{MensSCs Isolation and Culture}

Human MensSCs were obtained from menstrual blood of several healthy female donors ranging in age from 20 to 32 years, by using sterile Divacup during the first few days of the menstrual cycle. Samples were only taken after obtaining informed consent from individuals, under an approved institutional review board protocol according to guidelines by the Ethics Committee of Avicenna Research Institute for providing menstrual blood sample. The specimens were quickly illustrated into the falcon tube containing $2.5 \mu \mathrm{g} / \mathrm{ml}$ fungizone, $100 \mu \mathrm{g} / \mathrm{ml}$ streptomycin, $100 \mathrm{U} / \mathrm{ml}$ penicillin and $0.5 \mathrm{mM}$ EDTA in phosphate buffered saline without $\mathrm{Ca}^{2+}, \mathrm{Mg}^{2+}(\mathrm{PBS})$. The mononuclear cell fraction was separated by centrifugation over a Ficoll-Paque gradient; centrifuge at $600 \mathrm{~g}$ for $20 \mathrm{~min}$ at room temperature (RT). Cells at the interface were recovered and washed three times with PBS by centrifugation, $600 \mathrm{~g}$ for $20 \mathrm{~min}$ at room temperature. Cells resuspended in DMEM-F12 and plated in polysty- 
rene plastic $75-\mathrm{cm}^{2}$ tissue culture flasks. After 3 days, the non-adherent cell was removed by washing with PBS. Contaminated cells were eliminated by sequential passaging.

\subsection{Cell Seeding on the Scaffold}

Nanofibers scaffold should be sterilized before use so the samples were soaked infiltrated $70 \%$ ethanol for $2 \mathrm{~h}$ at room temperature (RT), then washed twice with media and left overnight in DMEM. After trypsinized and counted, $5 \times 10^{4}$ cells suspended in $50 \mu \mathrm{l}$ DMEM transferred to the surface of each prepared scaffolds. To adhere the cell on the surface of PCL, plate was incubated at $37^{\circ} \mathrm{C}$ for 45 minutes. After this time $50 \mu \mathrm{l}$ of culture medium was applied to each cellular scaffold every 30 minutes until $3 \mathrm{~h}(300 \mu \mathrm{L})$.

\subsection{Cell Morphology and Attachment Study on the PCL Scaffold}

To study the morphology and cell adhesion on the surface of the scaffold electron Microscopic studies were performed. In brief, after washing non-adherent cells with PBS, MensSCs has grown on scaffolds fixed in 3\% glutaraldehyde for $3 \mathrm{~h}$ at RT. The dehydration process is accomplished by passing the scaffold through a series of graded alcohol solutions (diluted from 100\% pure ethanol, Merk). All specimens were then coated with palladium-gold (Au-Pd) and viewed under scanning electron microscope (Philips XL30, Amsterdam, The Netherlands).

For observation of the diffusion of cell-seeded samples, hematoxylin and eosin staining was performed. Specimens were fixed at $10 \% \mathrm{v} / \mathrm{v}$ buffered formalin. Dehydration of the scaffold was done by a graded ethanol series, and then the scaffold embedded in paraffin. The specimens were cut into $10 \mu \mathrm{m}$-thick sections and stained with hematoxylin and eosin (H\&E) [12].

\subsection{MTT Assay}

To compare proliferate capability of MensSCs in 3D with 2D, cells were seeded at a concentration of $5 \times 10^{4}$ cells per well in 24-well plates on both scaffold and 2D culture systems. Cell proliferation was analyzed at days 4, 7 and 10 by MTT reduction test [13]. Culture medium was removed and replaced with $0.2 \mathrm{ml}$ medium without FBS; then, $20 \mu \mathrm{l}$ of MTT stock solution $(5 \mathrm{mg} / \mathrm{ml}$ ) was added to each well. After 3 hours incubation, the medium was removed and $100 \mu \mathrm{l}$ DMSO added then up \& down well to solve formazan crystal. Optical densities (OD) were measured at 570 using an ELISA reader (Labsystem Multiskan, Finland), with background subtraction at $670 \mathrm{~nm}$.

\subsection{Hepatic Differentiation Protocols}

Hepatic differentiation was performed with two protocols. For 2 days cultured cells were treated with $20 \mathrm{ng} / \mathrm{ml}$ EGF and $10 \mathrm{ng} / \mathrm{ml}$ bFGF, this is the same for both. Protocol 1: the cells were cultured in a culture medium consisting of DMEM-F12 supplemented with, $40 \mathrm{ng} / \mathrm{ml} \mathrm{HGF,} 10 \mathrm{ng} / \mathrm{ml} \mathrm{bFGF}$, and $50 \mu \mathrm{g} / \mathrm{ml}$ NTA for 14 days. The second step also continued until 14 days with $20 \mathrm{ng} / \mathrm{mL}$ OSM, $10^{-7} \mathrm{Mol} / \mathrm{L}$ DEX, 1X ITS+1 premix and 50 $\mu \mathrm{g} / \mathrm{ml}$ NTA. Protocol 2: in this protocol culture medium consisting of DMEM-F12 supplemented with, $40 \mathrm{ng} / \mathrm{ml}$ HGF, $10^{-7} \mathrm{Mol} / \mathrm{l}$ DEX, $1 \mathrm{X}$ ITS +1 premix and $50 \mu \mathrm{g} / \mathrm{ml}$ NTA for 14 days. In the second phase, OSM was replaced by HGF at a concentration of $10 \mathrm{ng} / \mathrm{ml}$ and continued until 28 days of differentiation. The plate was incubated at $37^{\circ} \mathrm{C}$ and culture media were replaced every second day for up to 30 days.

\subsection{Immunocytochemistry (ICC)}

After 30 days differentiation the culture, cells on the scaffold and 2D culture were fixed with 3\% glutaraldehyde for 1 hour at room temperature then washed with PBS. In the next step cell Permeabilized with $0.4 \%$ triton $\mathrm{X}-100$ for $20 \mathrm{~min}$. Washed cells were incubated overnight at $4^{\circ} \mathrm{C}$ with primary antibodies, including monoclonal mouse anti-human albumin (1:100), the cells were washed five times with PBS and incubated with fluorescein isothiocyanate (FITC)-labeled sheep anti-mouse IgG at $37^{\circ} \mathrm{C}$ for 45 minutes in the dark. After washing with PBS, cells were incubated with DAPI (4', 6-diamidino-2-phenylindole; 1:1000) for nuclear staining. The cells were visualized and observed by using a fluorescence microscope (Nikon, TE-2000, Tokyo, Japan). 


\subsection{ELISA Assay}

Study of albumin production was performed with ELISA assay. Conditioned media from the differentiated MensSCs cultured in 3D and 2D culture's system were collected at days $14 a n d ~ 30$ then frozen at $-20^{\circ} \mathrm{C}$ until assay. The conditioned media were assayed for ALB production using a quantitative enzyme-linked immunosorbent assay kit (ELISA) according to manufacturer's recipes. Finally, albumin concentration was calculated from a standard curve prepared from different dilutions of albumin standard. The conditioned media of undifferentiated MensSCs (day 0) was used as a negative control.

\subsection{RNA Extraction and Reverse Transcriptase-Polymerase}

\section{Chain Reaction (RT-PCR) Analysis}

RT-PCR was used to evaluate the expression of albumin (ALB), Alpha-fetoprotein (AFP), Tyrosine aminotransferase (TAT), and cytochrome P4507A1 (CYP7A1) in differentiated cells on the scaffold. Total RNA was isolated from cultured cells. Genomic DNA was digested from RNA samples by DNase I. Standard RT was performed using a Reverse RevertAid ${ }^{\mathrm{TM}}$ First Strand cDNA Synthesis Kit and $2 \mu \mathrm{g}$ of total RNA, $0.5 \mu \mathrm{g}$ oligo (dt18) per reaction, according to the manufacturer's instructions. The cDNA samples were subjected to polymerase chain reaction (PCR) amplification using human specific primers designed using different exons (Table 1). Amplification conditions were as follows: Initial denaturation at $95^{\circ} \mathrm{C}$ for 3 min followed by 35 cycles of denaturation at $94^{\circ} \mathrm{C}(30 \mathrm{Sec})$, annealing at $60^{\circ} \mathrm{C}(30 \mathrm{Sec})$, extension at $72^{\circ} \mathrm{C}(45 \mathrm{Sec})$ and a final polymerization at $72^{\circ} \mathrm{C}$ for $7 \mathrm{~min}$. Amplified DNA fragments were electrophoresed on $2 \%$ agarose gel and photographedon a UV transilluminator (Uvidoc, Cambridge, UK). As a positive control, human hepatoma cell line, HepG2, (Pasteur Institute, Tehran, Iran) was used.

\subsection{Statistical Analysis}

The data were analyzed by the Mann-Whitney test. The further analyses were performed by LSD. All grafts were depicted by a prism. A p-value less than 0.05 were considered as significant.

\section{Results}

\subsection{Characterization of Isolated MensSCs}

MensSCs adhered to the tissue culture flask a day after isolation. Expanded MensSCs had fibroblast-like shapes and morphologically conserved during passages. In order to find the cell characterization of the cultured cells, the surface CD markers were analyzed. To eliminate of contamination, the cells were passaged 3 times prior to experiments. Flow cytometric analysis of the cultured cells showed MensSCs regularly express the mesenchymal stem cell markers like CD73 (95.5\% \pm 0.4\%), CD90 (97.7\% $\pm 2.1 \%)$, CD44 (99.4\% $\pm 0.55 \%)$, CD105 (97.6\% $\pm 0.9 \%)$, while lacking surface expression of CD34 $(0.165 \% \pm 1.3 \%)$, CD45 $(0.940 \% \pm 0.6 \%)$ as hematopoietic markers. To evaluate the potential of the MensSCs, cells were differentiated into adipogenic and oesteogenic lineage. They were exposed to adipogenic and osteogenic media. The morphology of cells treated by adipogenic

Table 1. Primers and annealing temperatures used for reverse transcription polymerase chain reaction (RT-PCR) of liver specific gene expression.

\begin{tabular}{|c|c|c|c|}
\hline Primer & Sequence & $\begin{array}{c}\text { Annealing } \\
\text { temperature }\left({ }^{\circ} \mathrm{C}\right)\end{array}$ & Product size (bp) \\
\hline$A L B$ & $\begin{array}{l}\text { F 5'-GATGAGATGCCTGCTGACTTGC-3' } \\
R \text { 5'-CACGACAGAGTAATCAGGATGCC-3' }\end{array}$ & 60 & 147 \\
\hline$A F P$ & $\begin{array}{l}F \text { 5'-CATGAGCACTGTTGCAGAGGAGA-3' } \\
\text { R 5'-CGTGGTCAGTTTGCAGCATTCTG-3' }\end{array}$ & 60 & 113 \\
\hline$T A T$ & $\begin{array}{c}F \text { 5'-CTTCTGGGGCTATGTACCTCA-3' } \\
R \text { 5'-GGACTGTGATGACCACTCGGAT-3' }\end{array}$ & 55 & 165 \\
\hline CYP7A1 & $\begin{array}{l}\text { F 5'-CATGAGCACTGTTGCAGAGGAGA-3 } \\
R \text { 5'-ACTCGGTAGCAGAAAGAATACATC-3' }\end{array}$ & 60 & 388 \\
\hline$G A P D H$ & $\begin{array}{l}\text { F5'-CTCTCTGCTCCTCCTGTTCG-3' } \\
R \text { 5'-ACGACCAАATCCGTTGACTC-3' }\end{array}$ & 60 & 142 \\
\hline
\end{tabular}


media was changed and intra-cytoplasmic lipid droplets which were positive stained with Oil Red O. Alizarin red staining demonstrated the capability of the cells into osteoblasts. In both staining procedures undifferentiated MensSCs were negative controls (Figure 1).

\subsection{Evaluation of the MensSCs Seeded on the Scaffold}

The scanning electron microscopy (SEM) micrographs of the scaffolds before and after cell culture are shown in Figure 2. The scaffold has 3D, non-woven structure and consists of randomly oriented nanofibers. The region of diameter distribution of nanofibrous scaffold was ranging from $200-1500 \mathrm{~nm}$ that is similar to natural ECM. (Figure 2(A)). Figure 2(B) and Figure 2(C) show typical SEM micrographs of cell attachment and interaction with the surface of the scaffold. Morphology of the cells, migration, and proliferation is presented obviously. The result of H\&E staining indicated the proliferation and distribution of cultured cells on nanofibrous structure (Figure 2(D) and Figure 2(E)). The absorbance of the seeded cells on the scaffold was significantly higher than control cells in two dimensional culture systems (Figure 2(F)).

\subsection{Immunocytochemical Staining}

To confirm in vitro hepatic differentiation from MensSCs, we analyzed expression of ALB with two protocols in 2D and 3D culture systems. The differentiated MensSCs stained positively for ALB at day30. There was no difference between expression levels of ALB of cells differentiated under both protocols in 2D culture and also no difference between two groups of hepatocyte-like cells on scaffolds. However, the cells differentiated on
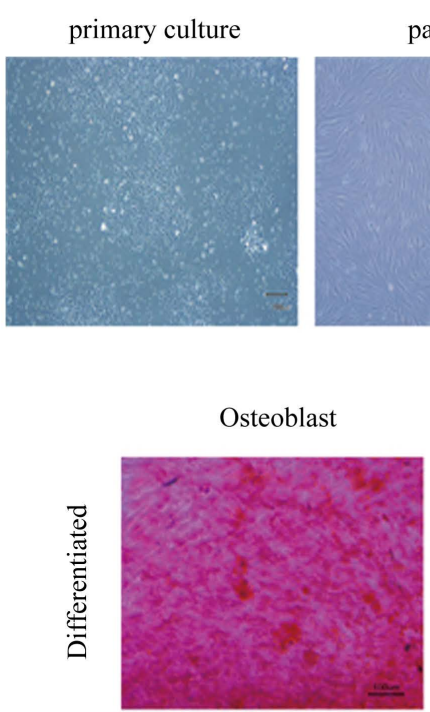

passage 5
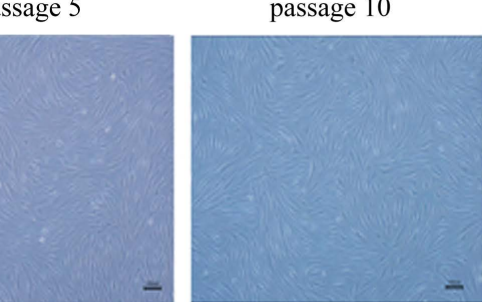

(a)
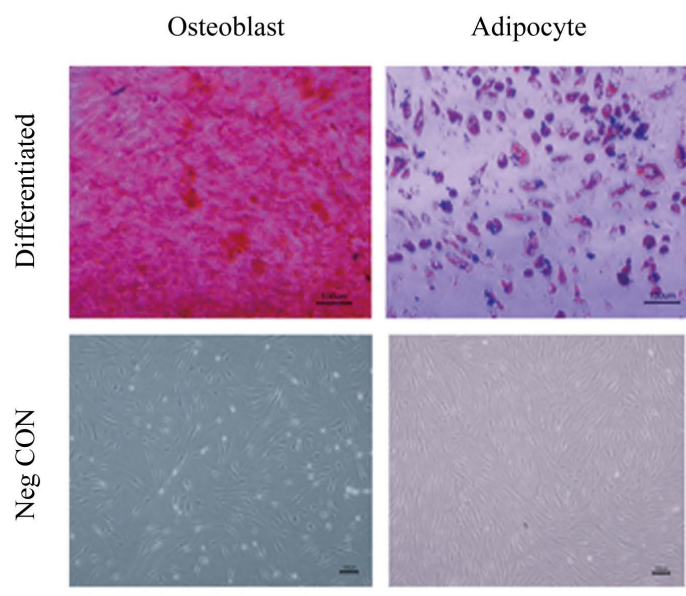

(b)
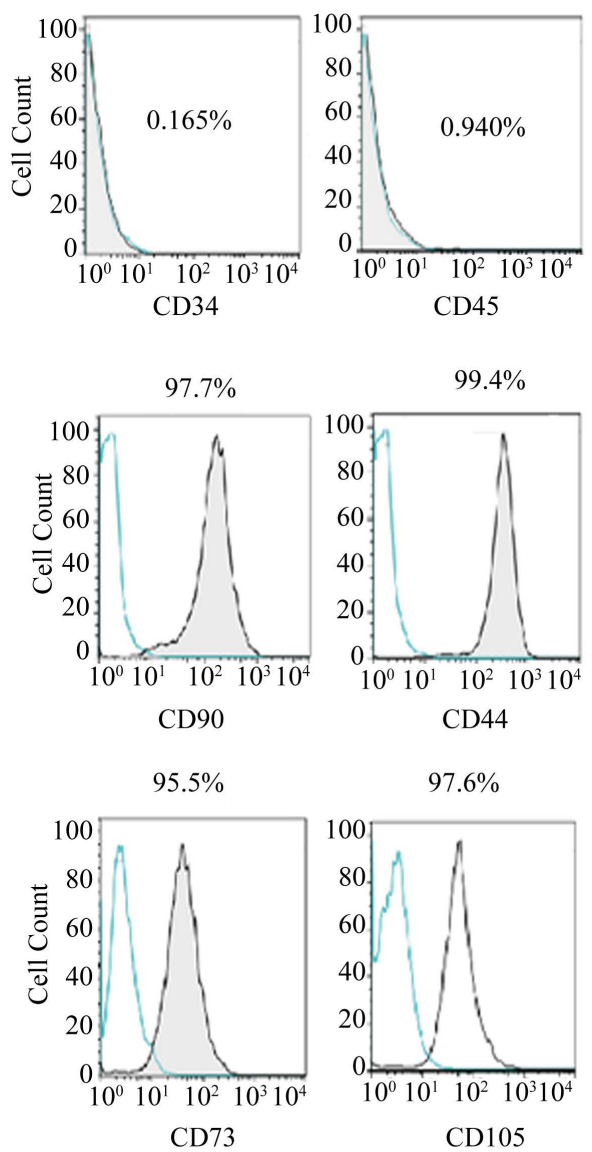

(c)

Figure 1. Characterization of MensSCs. (a) This figure shows the Spindle-like morphology of MensSCs at different times and passages. The cells conserved their morphology even in high passages; (b) Demonstrating of adipogenic and osteogenic capability of the cells with Oil Red O and Alizarin red staining; (c) Flow cytometric assay of MensSCs surface markers. 

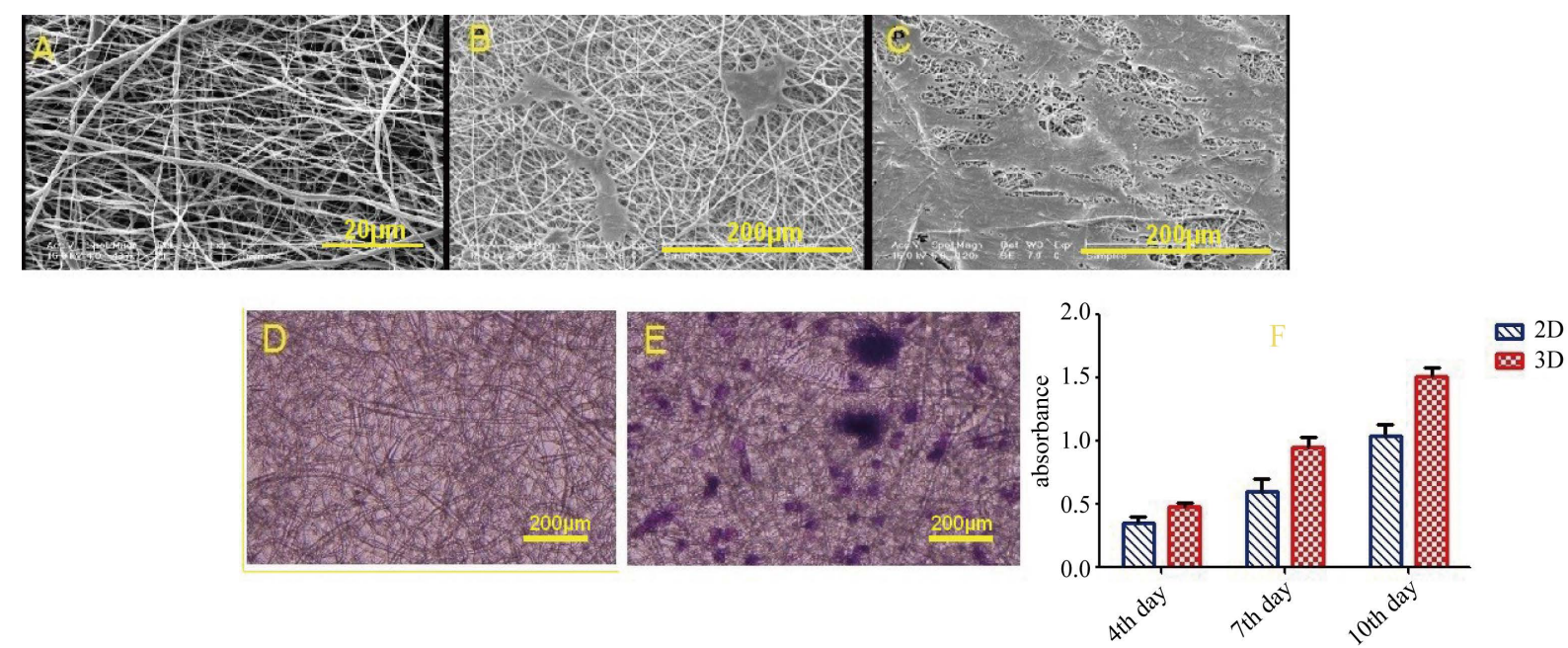

Figure 2. Scanning electron microscopy (SEM). (A) Scanning electron microscopy (SEM) images of electrospun PCL. The scaffold has 3D structure and similar to natural ECM; (B) (C) cells attachment and proliferation of MensSCs on the surface of the scaffold. at first and 10th day after cell seeded; (D) (E) H\&E staining results indicated the distribution of the cells on PCL scaffold before and after of cell seeding; (F) MTT assay showed the high proliferation of MensSCs in 3D cultures compared to $2 \mathrm{D}$ ones at 4 th, 7 th and 10 th days.

scaffolds showed significantly higher expression levels of this protein compared with other groups. The percentages of the differentiated cells and the intensity of the reactions of the antibodies were increased significantly compared with those in undifferentiated cultures. The expression of these protein markers was detected in human hepG2 hepatoma cells, used as positive control (Figure 3).

\subsection{ELISA Assay}

Albumin was secreted into the culture media and significantly increased on day 30 of differentiation. As shown in Figure 4, Undifferentiated MensSCs did not secrete ALB, whereas significantly increased In the process of differentiation. The levels of ALB in culture media from differentiated cells on the scaffold were higher than the 2D culture system. Our data indicated that MensSCs differentiated under protocol 1 produced greater amounts of ALB compared to cells induced with protocol 2 in both system cultures. On day 14 of differentiation, the differences in albumin levels between differentiated cells in 2D and 3D systems were negligible in both groups ( $\mathrm{P}$ $<0.05)$.

\subsection{Hepatic Gene Expression}

Hepatocyte-like cell differentiation was confirmed by RT-PCR hepatocyte-specific genes, namely albumin (ALB), $\alpha$-Fetoprotein (AFP), cytochrome P450 subunits 7a1 (Cyp7a1), tyrosine aminotransferase (TAT) and GAPDH was used as an internal control. In this study, the undifferentiated MensSCs did not express mRNA of the hepatocyte lineage genes. As shown in Figure 5 ALB expression in all groups was up regulated than undifferentiated cells, but in comparison to hepatoma cells as positive control was less. Whereas no significant change was detected in ALB expression between different protocols, however, expression of the gene was slightly better on the scaffold. The semi-quantitative RT-PCR showed that the expression of TAT in differentiated cells by Protocols 1 and cultured on the scaffold was at a higher level compared to others. The upper regulation of CYP7a1 as a liver-specific gene was shown in cultured cells on a scaffold which exposed to hepatogenic media by protocol 1. However, other groups significantly expressed CYP7a1 at mRNA levels. In case of AFP low expression of this gene was detected in differentiated cells by both protocols and culture systems to compare to control positive cells.

\section{Discussion}

Many researchers are experimenting different adult stem cells to be used for tissue regeneration. Recently a 
Protocol 1

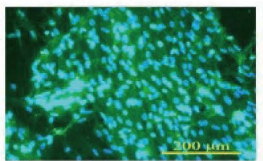

2D

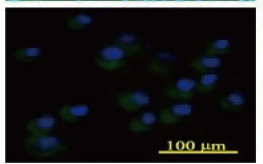

Protocol 2
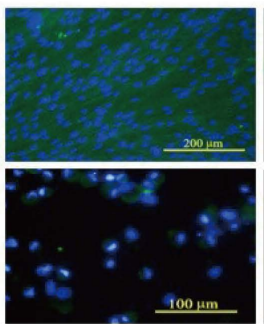

Pos CON
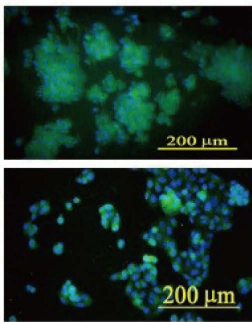

Neg CON
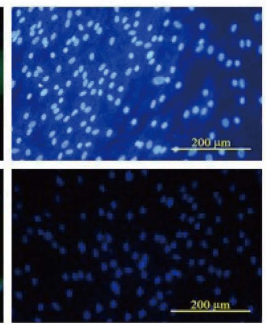

Figure 3. ICC staining of albumin. Positive staining of albumin was evidenced in the all groups of differentiated cells on day 30. However, the cells differentiated on scaffolds showed approximately higher expression levels of this protein compared with others. The human hepatoma cell line (hepG2) as positive and undifferentiated cells as negative control groups were used.

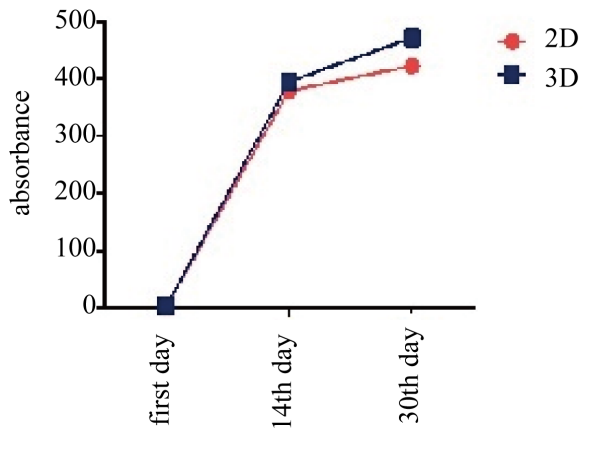

Protocol 1

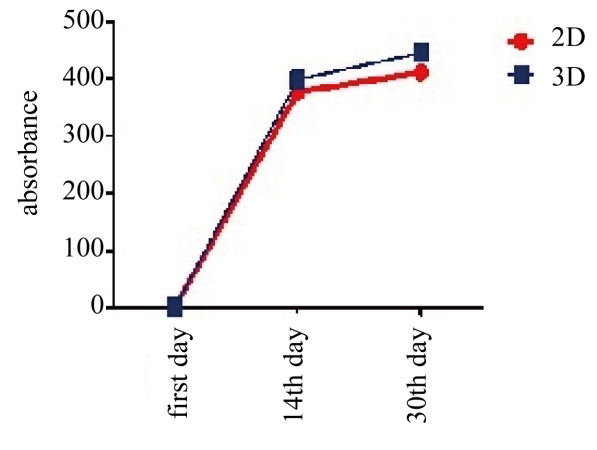

Protocol 2

Figure 4. ELISA Assay. Albumin (ALB) production by MensSCs in 3D and 2D culture systems at 0,14 , and 30 days was shown. ALB product was increased during differentiation in the presence of growth factors and significantly 30 days had higher level in 3D culture compared with 2D culture. There was no significant difference between two differentiated protocols. The modification was measured spectrophotometrically at a wavelength of $450 \mathrm{~nm}$.

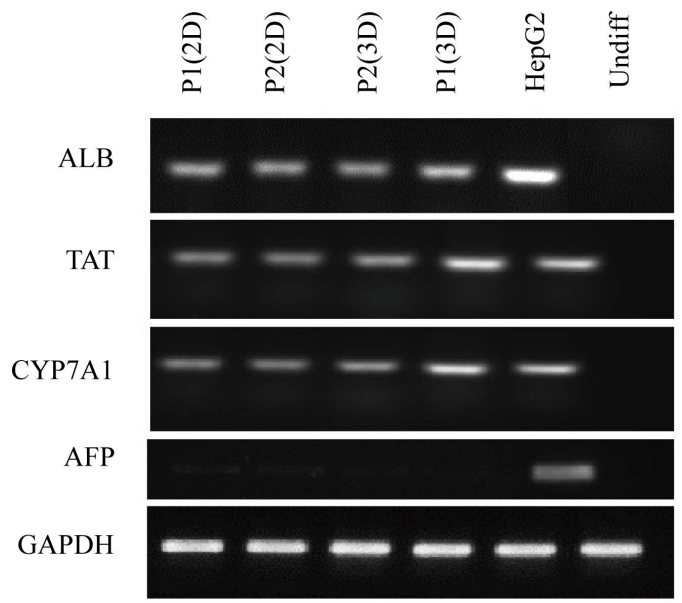

Figure 5. Hepatic gene expression. RT-PCR analysis of liver-specific gene expression by MensSCs in $2 \mathrm{D}$ and $3 \mathrm{D}$ culture systems in the presence of exogenous growth factors are shown on 30th day. The expression of, albumin (ALB), tyrosine aminotransferase (TAT), cytochrome P450 subunit 7a1 (Cyp7a1) and $\alpha$-fetoprotein (AFP), during in vitro differentiation are shown. In the 3D culture system, mRNA expression of ALB, TAT and CYP7A1 were detected better than 2D system The AFP gene was not expressed in both differentiated protocols and culture systems. The human hepatoma cell line (hepG2) as positive and undifferentiated cells as negative controls was used. 
novel adult stem cell described that can be obtained from women's menstrual blood derived from the endometrium. This source of stem cells non-invasively isolated to provide a renewable source of stem cells from childbearing women [10] [14]-[18]. In this study we, characterized and differentiated MensSCs to hepatocyte on nanofibrous scaffold PCL by two protocols and compared to 2D culture system. Ability to differentiate stem cells into hepatocytes on natural scaffolds has been studied in various experiments [19]-[21]. However nanofibers are gradually more being used for tissue engineering and have advantages over traditional scaffolds because of increased surface area-to-volume ratio, which increases cell to scaffold interactions [10]. Nanofibrous PCL scaffolds are being extensively used as synthetic tissue by supporting matrices for various tissue regeneration [22][24]. As described, we investigated the hepatic differentiation of MensSCs within a 3D PCL scaffold-culture system on dishes supplemented with exogenous growth factors. The results of cell attachment and proliferation revealed that this highly porous network is sufficient for the survival of cells for extended periods of time.

Characterization of MensSCs prior to assessment of the potential of MensSCs to differentiate into hepatocytes was evaluated. High levels of mesenchymal stem cell markers [25] such as CD 44, CD 90, CD 73, and CD 105 and low expression of hematopoietic markers, CD 34 and CD 45, confirmed this source of stem cell as multipotent stromal cells. The Differentiation ability of isolated cells to osteogenic and adipogenic lineages indicated the nature of MensSCs. The electrospunnanofibrous scaffolds have been shown to promote cell attachment, proliferation, and differentiation [26] [27]. The pore size of the hybrid polymer prepared by us was within 200 $1500 \mathrm{~nm}$ range, which causes slow distribution of small molecules, metabolites and macromolecules. Data of cell attachment and proliferation exposed that this highly porous scaffold is suitable for extended and differentiation of cells. Expression of biochemical markers, particularly albumin in differentiated hepatocytes is commonly used to identify the performance of stem cell derived cells [28]. Expression of hepatic differentiation marker of protein and mRNA levels in the differentiated cells dependent on the protocol and culture system. The Level of albumin-positive cells was higher when MensSCs were cultured on the scaffold as compared to that the 2D culture system. Different protocols were not marked influence on the expression of albumin. Expression of TAT at mRNA levels as late hepatic markers further confirms hepatocyte maturation. The Cells differentiated under protocol 1 and 3D culture system displayed an upper level of TAT at the mRNA level while differentiated cells by the 2D system had low expression of this. Oncoming Expression of CYP7a1, unique marker of mature hepatocytes [29] indicates the functional properties of the differentiated cells. Consistent with these results CYP7A1 was significantly higher in differentiated MensSCs under Protocol 1 and it was high exertion on cultured cells on the scaffold. On the other hand, the expression of AFP (early marker of fetal liver) during the differentiation, reduced. Concentrations of this mRNA decline from profuse levels in fetal liver in very low levels in the adult organ and it can suggest hepatocyte-like cells were mature [30] [31]. Increasing in the levels of albumin in the cultured cells 30 days after differentiation was used as evidence for the functionality of the differentiated. In comparison with 2D culture, higher production levels of albumin, in differentiated cells on the scaffold were obtained $(\mathrm{P}<0.05)$ which may suggest the conductive effect of the ECM-like structure for MensSCs differentiation. It seems that the elimination of FBS from different media creates the required conditions for cells to switch to hepatic differentiation. Taken together, It assumes that the existence of biomimetic nanofibers provide a nano environment similar to natural ECM, which would improve the biological activity of growth factors and cytokines for inducing differentiation. Finding a suitable scaffold for connection increasing growth and differentiation of hepatocytes cells can be an essential step on medicine, scientific goals in the field of liver tissue engineering. So, introducing PCL scaffold as an ideal scaffold for differentiation of MensSCs as plentiful and non-invasive source of stem cells in 3D culture is the best conclusion of innovation the present study. In vivo studies regarding to functionality of this source will bring new insights into the future clinical applications based on stem cell technology for the treatment of chronic liver diseases.

\section{Conclusion}

The evidences presented in this paper clearly show that the PCL scaffold can support proliferation and hepatogenic differentiation of MensSCs. However, very little is known about the stimulating effects of this hybrid polymer on hepatic differentiation. In summary, our study demonstrates that a unique population of stromal stem cells can be collected, isolated, characterized, expanded, from human menstrual blood and differentiation into hepatocyte-like cell on three dimensional nanofibrous scaffolds. 


\section{Acknowledgements}

We would like to thank Avicenna Research Institute for offering the grant.

\section{Conflict of Interest}

The authors indicate no potential conflicts of interest.

\section{References}

[1] Haridass, D., Narain, N. and Ott, M. (2008) Hepatocyte Transplantation: Waiting for Stem Cells. Current Opinion in Organ Transplantation, 13, 627-632. http://dx.doi.org/10.1097/MOT.0b013e328317a44f

[2] Kim, S.J., Kim, M.R., Oh, J.S., Han, I. and Shin, S.W. (2009) Effects of Polycaprolactone-Tricalcium Phosphate, Recombinant Human Bone Morphogenetic Protein-2 and Dog Mesenchymal Stem Cells on Bone Formation: Pilot Study in Dogs. Yonsei Medical Journal, 50, 825-831. http://dx.doi.org/10.3349/ymj.2009.50.6.825

[3] Yilgor, P., Sousa, R.A., Reis, R.L., Hasirci, N. and Hasirci, V. (2008) 3D Plotted PCL Scaffolds for Stem Cell Based Bone Tissue Engineering. Macromolecular Symposia, 269, 92-99. http://dx.doi.org/10.1002/masy.200850911

[4] Kalervo Väänänen, H. (2005) Mesenchymal Stem Cells. Annals of Medicine, 37, 469-479. http://dx.doi.org/10.1080/07853890500371957

[5] Toma, C., Pittenger, M.F., Cahill, K.S., Byrne, B.J. and Kessler, P.D. (2002) Human Mesenchymal Stem Cells Differentiate to a Cardiomyocyte Phenotype in the Adult Murine Heart. Circulation, 105, 93-98. http://dx.doi.org/10.1161/hc0102.101442

[6] Zurita, M. and Vaquero, J. (2004) Functional Recovery in Chronic Paraplegia after Bone Marrow Stromal Cells Transplantation. Neuroreport, 15, 1105-1108. http://dx.doi.org/10.1097/00001756-200405190-00004

[7] Vilquin, J. and Rosset, P. (2010) Mesenchymal Stem Cells in Bone and Cartilage Repair: Current Status. Regenerative Medicine, 1, 589-604. http://dx.doi.org/10.2217/17460751.1.4.589

[8] Bentz, E.K., Kenning, M., Schneeberger, C., Kolbus, A., Huber, J.C., Hefler, L.A. and Tempfer, C.B. (2010) OCT-4 Expression in Follicular and Luteal Phase Endometrium: A Pilot Study. Reproductive Biology and Endocrinology, 8, 38. http://dx.doi.org/10.1186/1477-7827-8-38

[9] De Coppi, P., Bartsch, G., Siddiqui, M.M., Xu, T., Santos, C.C., Perin, L. and Atala, A. (2007) Isolation of Amniotic Stem Cell Lines with Potential for Therapy. Nature Biotechnology, 25, 100-106. http://dx.doi.org/10.1038/nbt1274

[10] Borlongan, C.V., Kaneko, Y., Maki, M., Yu, S.J., Ali, M., Allickson, J.G. and Sanberg, P.R. (2010) Menstrual Blood Cells Display Stem Cell-Like Phenotypic Markers and Exert Neuroprotection Following Transplantation in Experimental Stroke. Stem Cells and Development, 19, 439-452. http://dx.doi.org/10.1089/scd.2009.0340

[11] Lin, J., Xiang, D., Zhang, J.L., Allickson, J. and Xiang, C. (2011) Plasticity of Human Menstrual Blood Stem Cells Derived from the Endometrium. Journal of Zhejiang University Science B, 12, 372-380. http://dx.doi.org/10.1631/jzus.B1100015

[12] Cho, S.W., Kim, I.K., Lim, S.H., Kim, D.I., Kang, S.W., Kim, S.H. and Kim, B.S. (2004) Smooth Muscle-Like Tissues Engineered with Bone Marrow Stromal Cells. Biomaterials, 25, 2979-2986. http://dx.doi.org/10.1016/j.biomaterials.2003.09.068

[13] Mosmann, T. (1983) Rapid Colorimetric Assay for Cellular Growth and Survival: Application to Proliferation and Cytotoxicity Assays. Journal of Immunological Methods, 65, 55-63. http://dx.doi.org/10.1016/0022-1759(83)90303-4

[14] Patel, A.N., Park, E., Kuzman, M., Benetti, F., Silva, F.J. and Allickson, J.G. (2008) Multipotent Menstrual Blood Stromal Stem Cells: Isolation, Characterization, and Differentiation. Cell Transplantation, 17, 303-311. http://dx.doi.org/10.3727/096368908784153922

[15] Patel, A.N. and Silva, F. (2008) Menstrual Blood Stromal Cells: The Potential for Regenerative Medicine. Regenerative Medicine, 3, 443-444. http://dx.doi.org/10.2217/17460751.3.4.443

[16] Van Phuc, P., Lam, D.H., Ngoc, V.B., Thu, D.T., Nguyet, N.T.M. and Ngoc, P.K. (2011) Production of Functional Dendritic Cells from Menstrual Blood-A New Dendritic Cell Source for Immune Therapy. In Vitro Cellular \& Developmental Biology-Animal, 47, 368-375. http://dx.doi.org/10.1007/s11626-011-9399-2

[17] Allickson, J.G., Sanchez, A., Yefimenko, N., Borlongan, C.V. and Sanberg, P.R. (2011) Recent Studies Assessing the Proliferative Capability of a Novel Adult Stem Cell Identified in Menstrual Blood. The Open Stem Cell Journal, 3, 4. http://dx.doi.org/10.2174/1876893801103010004

[18] Allickson, J. and Xiang, C. (2012) Human Adult Stem Cells from Menstrual Blood and Endometrial Tissue. Journal of Zhejiang University-Science B, 13, 419-420. http://dx.doi.org/10.1631/jzus.B1200062 
[19] Glicklis, R., Shapiro, L., Agbaria, R., Merchuk, J.C. and Cohen, S. (2000) Hepatocyte Behavior within Three-Dimensional Porous Alginate Scaffolds. Biotechnology and Bioengineering, 67, 344-353. http://dx.doi.org/10.1002/(SICI)1097-0290(20000205)67:3<344::AID-BIT11>3.0.CO;2-2

[20] Baharvand, H., Hashemi, S.M., Ashtiani, S.K. and Farrokhi, A. (2006) Differentiation of Human Embryonic Stem Cells into Hepatocytes in 2D and 3D Culture Systems in Vitro. International Journal of Developmental Biology, 50, 645. http://dx.doi.org/10.1387/ijdb.052072hb

[21] Ong, S.Y., Dai, H. and Leong, K.W. (2006) Inducing Hepatic Differentiation of Human Mesenchymal Stem Cells in Pellet Culture. Biomaterials, 27, 4087-4097. http://dx.doi.org/10.1016/j.biomaterials.2006.03.022

[22] Yoshimoto, H., Shin, Y.M., Terai, H. and Vacanti, J.P. (2003) A Biodegradable Nanofiber Scaffold by Electrospinning and Its Potential for Bone Tissue Engineering. Biomaterials, 24, 2077-2082. http://dx.doi.org/10.1016/S0142-9612(02)00635-X

[23] Guex, A.G., Romano, F., Marcu, I.C., Tevaearai, H.T., Ullrich, N.D. and Giraud, M.N. (2012) Culture of Cardiogenic Stem Cells on PCL-Scaffolds: Towards the Creation of Beating Tissue Constructs. IASTED Conference Proceedings, Vol. 791. http://dx.doi.org/10.2316/P.2013.791-080

[24] Hoveizi, E., Khodadadi, S., Tavakol, S., Karima, O. and Nasiri-Khalili, M.A. (2014) Small Molecules Differentiate Definitive Endoderm from Human Induced Pluripotent Stem Cells on PCL Scaffold. Applied Biochemistry and Biotechnology, 173, 1727-1736. http://dx.doi.org/10.1007/s12010-014-0960-9

[25] Haynesworth, S.E., Barer, M.A. and Caplan, A.I. (1992) Cell Surface Antigens on Human Marrow-Derived Mesenchymal Cells Are Detected by Monoclonal Antibodies. Bone, 13, 69-80. http://dx.doi.org/10.1016/8756-3282(92)90363-2

[26] Gillette, B.M., Rossen, N.S., Das, N., Leong, D., Wang, M., Dugar, A. and Sia, S.K. (2011) Engineering Extracellular Matrix Structure in 3D Multiphase Tissues. Biomaterials, 32, 8067-8076. http://dx.doi.org/10.1016/j.biomaterials.2011.05.043

[27] Rim, N.G., Shin, C.S. and Shin, H. (2013) Current Approaches to Electrospun Nanofibers for Tissue Engineering. Biomedical Materials, 8, Article ID: 014102. http://dx.doi.org/10.1088/1748-6041/8/1/014102

[28] Snykers, S., Vanhaecke, T., De Becker, A., Papeleu, P., Vinken, M., Van Riet, I. and Rogiers, V. (2007) Chromatin Remodeling Agent Trichostatin A: A Key-Factor in the Hepatic Differentiation of Human Mesenchymal Stem Cells Derived of Adult Bone Marrow. BMC Developmental Biology, 7, 24. http://dx.doi.org/10.1186/1471-213X-7-24

[29] Sancho-Bru, P., Roelandt, P., Narain, N., Pauwelyn, K., Notelaers, T., Shimizu, T. and Verfaillie, C. (2011) Directed Differentiation of Murine-Induced Pluripotent Stem Cells to Functional Hepatocyte-Like Cells. Journal of Hepatology, 54, 98-107. http://dx.doi.org/10.1016/j.jhep.2010.06.014

[30] Cai, J., Zhao, Y., Liu, Y., Ye, F., Song, Z., Qin, H., et al. (2004) Directed Differentiation of Human Embryonic Stem Cells into Functional Hepatic Cells. Hepatology, 45, 1229-1239. http://dx.doi.org/10.1002/hep.21582

[31] Basma, H., Soto-Gutiérrez, A., Yannam, G.R., Liu, L., Ito, R., Yamamoto, T. and Fox, I.J. (2009) Differentiation and Transplantation of Human Embryonic Stem Cell-Derived Hepatocytes. Gastroenterology, 136, 990-999. http://dx.doi.org/10.1053/j.gastro.2008.10.047 